\title{
A Taxonomic Study of the Genus Streptomyces by Analysis of Ribosomal Protein AT-L30
}

\author{
KOZO OCHI* \\ National Food Research Institute, 2-1-2 Kannondai, Tsukuba, Ibaraki 305, Japan
}

\begin{abstract}
The ribosomal AT-L30 proteins from 81 species of the genus Streptomyces as listed by Williams et al. in Bergey's Manual of Systematic Bacteriology were analyzed. My results provided further evidence that the genus Streptomyces is well circumscribed. On the basis of levels of AT-L30 N-terminal amino acid sequence homology, the strains were classified into four groups (groups I to IV) and a nongrouped category, whose members contained amino acid sequences characteristic of each species. A phylogenetic tree constructed on the basis of the levels of similarity of the amino acid sequences revealed the existence of six clusters within the genus. The first cluster contains the members of groups I and II together with several other species; the second cluster contains the members of groups III and IV and several other species; the third cluster contains Streptomyces ramulosus and Streptomyces ochraceiscleroticus; the fourth cluster contains only Streptomyces rimosus; the fifth cluster contains Streptomyces aurantiacus and Streptomyces tubercidicus; and the sixth cluster contains Streptomyces albus and Streptomyces sulphureus. Considerable agreement between the results of the AT-L30 analyses and the results of numerical phenetic classification was found, although there were numerous disagreements in details. For example, four groups (groups I to IV) defined by the AT-L30 analysis data did not correlate with the aggregate groups defined by numerical classification. In general, but not always, the species classified in a particular cluster in the numerical classification system had the same or similar AT-L30 terminal amino acid sequences. The AT-L30 analysis data were more consistent with the 16S rRNA analysis data than with the numerical classification data, indicating that there was a good correlation between the four groups defined by AT-L30 analysis data and the aggregate groups defined by $16 \mathrm{~S}$ rRNA analysis data. I stress that discrepancies between results of phenetic analyses and results of phylogenetic analyses should be taxonomically significant and can be resolved by other taxonomic approaches, such as DNA relatedness analysis.
\end{abstract}

The genus Streptomyces of the family Streptomycetaceae contains the largest number of species among the genera of the Actinomycetales and can be separated from other actinomycete genera with wall chemotype I by using a combination of chemical and morphological properties (reviewed in references 2, 10, and 33). Traditionally, streptomycete systematics has been based mainly on morphology, pigmentation, and physiological properties, but increasing weight is now given to chemical and genetic features $(2,3,9,11,15,28)$, especially for generic circumspection. As mentioned by O'Donnell (27), analysis of quantitative data by appropriate cluster analysis techniques may be essential for the characterization of streptomycetes at the subgeneric level. Because of importance of the genus Streptomyces as a source of novel antibiotics, the number of proposed streptomycete species, including those only cited in the patent literature, is more than 3,000 . The names of 378 validly described streptomycete species are listed on the Approved Lists of Bacterial Names (29).

Many attempts to delimit Streptomyces species have been made. In particular, a large-scale numerical phenetic survey of the genus Streptomyces and related taxa was performed by Williams et al. (34) to clarify the infrastructure of the genus; 394 Streptomyces type cultures were examined for 139 unit characters, and the data were analyzed statistically. The resulting classification indicated that the type strains of Streptomyces species were distributed in 23 major clusters (containing four or more strains), 20 minor clusters (containg two or three strains), and 25 clusters containing a single member. The minor clusters and the single-member clusters were considered species by Williams et al., and the major clusters were consid-

* Phone: 0298-38-8125. Fax: 0298-38-7996. ered species complexes. These results of this study are summarized in Bergey's Manual of Systematic Bacteriology (33).

A numerical phenetic survey of Streptomyces species was also performed by Kämpfer et al. (8). The phenetic data of these authors in most cases confirmed the existence of the major phena found in the study of Williams et al. (34), although only some of the cluster groups defined in the study of Williams et al. were detected by Kämpfer et al. Data which describe DNA relatedness among strains are also valuable for taxonomy, especially at the species level, and such data have been applied to streptomycetes by Labeda and Lyons (12-14). The phenetic clustering of these organisms actually reflects their genomic relationships as determined by DNA relatedness analyses and rRNA-based analyses $(1,35)$.

On the basis of the heterogeneity of the ribosomal proteins of Streptomyces species, I (17) developed a novel method for identifying and classifying actinomycetes. Ribosomal protein patterns determined by two-dimensional polyacrylamide gel electrophoresis (PAGE) could be used for Streptomyces taxonomy at the species level, while analysis of ribosomal AT-L30 proteins (homologous to Escherichia coli L30 protein) could be used to classify actinomycetes at the genus level $(18,19,21,23$, $25,26)$. The latter method is based on the electrophoretic mobilities of the AT-L30 proteins and N-terminal amino acid sequences. L30 protein analysis has been proven to be effective in the taxonomy of not only actinomycetes but also other eubacteria $(20,22)$. Witt and Stackebrandt $(35)$ have proposed that the genera Streptoverticillium and Streptomyces should be united on the basis of their high levels of phylogenetic and phenetic similarity. Wellington et al. (32) have proposed that the genus Kitasatosporia, whose members' cell walls contain similar amounts of the LL and meso isomers of diaminopimelic acid, as well as glycine and galactose, is a synonym of the genus Streptomyces. Recent AT-L30 sequence analysis data have con- 
TABLE 1 . Strains used in this study

\begin{tabular}{|c|c|c|}
\hline Species or subspecies & Strain & $\begin{array}{l}\text { Cluster of } \\
\text { Williams }^{\text {et al. }}{ }^{a}\end{array}$ \\
\hline Streptomyces aburaviensis & $\operatorname{JCM} 4613^{\mathrm{T}}\left(=\operatorname{ATCC} 23869^{\mathrm{T}}\right)^{b}$ & A-2 \\
\hline Streptomyces albidoflavus & $\mathrm{JCM} 4446^{\mathrm{T}}\left(=\right.$ ATCC $\left.25422^{\mathrm{T}}\right)$ & A-1A \\
\hline Streptomyces alboflavus & JCM $4615^{\mathrm{T}}\left(=\operatorname{ATCC} 12626^{\mathrm{T}}\right)$ & E-54 \\
\hline $\begin{array}{l}\text { Streptomyces albus subsp. } \\
\text { albus }\end{array}$ & $\mathrm{JCM} 4450^{\mathrm{T}}\left(=\operatorname{ATCC} 25426^{\mathrm{T}}\right)$ & A-16 \\
\hline Streptomyces amakusaensis & $\mathrm{JCM} 4617^{\mathrm{T}}\left(=\operatorname{ATCC} 23876^{\mathrm{T}}\right)$ & $\mathrm{B}^{c}$ \\
\hline Streptomyces aminophilus & $\mathrm{JCM} 4619^{\mathrm{T}}\left(=\right.$ ATCC $\left.13558^{\mathrm{T}}\right)$ & $\mathrm{A}-16^{d}$ \\
\hline Streptomyces antibioticus & $\mathrm{JCM} 4620^{\mathrm{T}}\left(=\mathrm{ATCC} 23879^{\mathrm{T}}\right)$ & A-31 \\
\hline Streptomyces anulatus & JCM $4721^{\mathrm{T}}\left(=\right.$ ATCC $\left.27416^{\mathrm{T}}\right)$ & $A-1 B$ \\
\hline Streptomyces atroolivaceus & $\mathrm{JCM} 4345^{\mathrm{T}}\left(=\right.$ ATCC $\left.19725^{\mathrm{T}}\right)$ & A-3 \\
\hline Streptomyces aurantiacus & JCM $4453^{\mathrm{T}}\left(=\right.$ ATCC $\left.19822^{\mathrm{T}}\right)$ & $C-45$ \\
\hline Streptomyces aurantiogriseus & JCM $4346^{\mathrm{T}}\left(=\right.$ ATCC $\left.19887^{\mathrm{T}}\right)$ & $\mathrm{A}^{c}$ \\
\hline Streptomyces aureofaciens & JCM $4624^{\mathrm{T}}\left(=\right.$ ATCC $\left.23884^{\mathrm{T}}\right)$ & A-14 \\
\hline Streptomyces badius & JCM $4350^{\mathrm{T}}\left(=\right.$ ATCC $\left.19888^{\mathrm{T}}\right)$ & $\mathrm{C}^{c}$ \\
\hline Streptomyces bambergiensis & $\mathrm{JCM} 4728^{\mathrm{T}}\left(=\right.$ ATCC $\left.13879^{\mathrm{T}}\right)$ & $\mathbf{A}^{c}$ \\
\hline Streptomyces bikiniensis & JCM $4011^{\mathrm{T}}\left(=\right.$ ATCC $\left.11062^{\mathrm{T}}\right)$ & F-64 \\
\hline Streptomyces bluensis & JCM $4729^{\mathrm{T}}\left(=\right.$ ATCC $\left.27420^{\mathrm{T}}\right)$ & $\mathrm{A}-39^{e}$ \\
\hline Streptomyces cacaoi & JCM $4352^{\mathrm{T}}\left(=\right.$ ATCC $\left.19732^{\mathrm{T}}\right)$ & $\mathrm{A}-16^{d}$ \\
\hline Streptomyces californicus & $\mathrm{JCM} 4567^{\mathrm{T}}\left(=\right.$ ATCC $\left.19734^{\mathrm{T}}\right)$ & A-9 \\
\hline Streptomyces canus & $\mathrm{JCM} 4569^{\mathrm{T}}\left(=\right.$ ATCC $\left.19737^{\mathrm{T}}\right)$ & A-25 \\
\hline Streptomyces cellulosae & $\mathrm{JCM} 4462^{\mathrm{T}}\left(=\operatorname{ATCC} 25439^{\mathrm{T}}\right)$ & A-13 \\
\hline Streptomyces chattanoogensis & $\mathrm{JCM} 4571^{\mathrm{T}}\left(=\right.$ ATCC $\left.19739^{\mathrm{T}}\right)$ & A-35 \\
\hline Streptomyces chromofuscus & $\operatorname{JCM} 4354^{\mathrm{T}}\left(=\operatorname{ATCC} 23896^{\mathrm{T}}\right)$ & A-15 \\
\hline Streptomyces cyanoalbus & $\operatorname{JCM} 4363^{\mathrm{T}}\left(=\right.$ ATCC $\left.23902^{\mathrm{T}}\right)$ & $\mathrm{A}-37^{d}$ \\
\hline $\begin{array}{l}\text { Streptomyces diastaticus } \\
\text { subsp. diastaticus }\end{array}$ & $\mathrm{JCM} 4745^{\mathrm{T}}\left(=\operatorname{ATCC} 3315^{\mathrm{T}}\right)$ & A-19 \\
\hline Streptomyces exfoliatus & $\operatorname{JCM} 4366^{\mathrm{T}}\left(=\operatorname{ATCC} 19750^{\mathrm{T}}\right)$ & A-5 \\
\hline Streptomyces filipinensis & JCM $4369^{\mathrm{T}}\left(=\right.$ ATCC $\left.23905^{\mathrm{T}}\right)$ & A-30 \\
\hline Streptomyces finlayi & $\mathrm{JCM} 4637^{\mathrm{T}}\left(=\right.$ ATCC $\left.23906^{\mathrm{T}}\right)$ & $\mathrm{I}^{c}$ \\
\hline Streptomyces flaveolus & JCM $4577^{\mathrm{T}}\left(=\right.$ ATCC $\left.19754^{\mathrm{T}}\right)$ & A-24 \\
\hline Streptomyces flaveus & $\mathrm{JCM} 3035^{\mathrm{T}}\left(=\right.$ ATCC $\left.15332^{\mathrm{T}}\right)$ & A- $19^{e}$ \\
\hline Streptomyces fradiae & JCM $4579^{\mathrm{T}}\left(=\right.$ ATCC $\left.19760^{\mathrm{T}}\right)$ & G-68 \\
\hline Streptomyces fragilis & JCM $4187^{\mathrm{T}}\left(=\right.$ ATCC $\left.23908^{\mathrm{T}}\right)$ & $\mathrm{G}^{c}$ \\
\hline Streptomyces fulvissimus & JCM $4129^{\mathrm{T}}\left(=\right.$ ATCC $\left.27431^{\mathrm{T}}\right)$ & A-10 \\
\hline Streptomyces glaucescens & $\mathrm{JCM} 4377^{\mathrm{T}}\left(=\right.$ ATCC $\left.23622^{\mathrm{T}}\right)$ & A-28 \\
\hline Streptomyces graminofaciens & $\mathrm{JCM} 4762^{\mathrm{T}}\left(=\right.$ ATCC $\left.12705^{\mathrm{T}}\right)$ & A-26 \\
\hline Streptomyces griseoflavus & JCM $4479^{\mathrm{T}}\left(=\right.$ ATCC $\left.25456^{\mathrm{T}}\right)$ & A-37 \\
\hline Streptomyces griseoincarnatus & $\operatorname{JCM} 4381^{\mathrm{T}}\left(=\operatorname{ATCC} 23917^{\mathrm{T}}\right)$ & $\mathrm{A}-13^{d}$ \\
\hline Streptomyces griseoluteus & $\mathrm{JCM} 4765^{\mathrm{T}}\left(=\right.$ ATCC $\left.12768^{\mathrm{T}}\right)$ & C-43 \\
\hline Streptomyces griseoruber & $\mathrm{JCM} 4642^{\mathrm{T}}\left(=\operatorname{ATCC} 23919^{\mathrm{T}}\right)$ & A-21 \\
\hline Streptomyces griseoviridis & JCM $4643^{\mathrm{T}}\left(=\right.$ ATCC $\left.23920^{\mathrm{T}}\right)$ & A-17 \\
\hline Streptomyces griseus & JCM $4644^{\mathrm{T}}\left(=\right.$ ATCC $\left.23921^{\mathrm{T}}\right)$ & $\mathrm{A}-1 \mathrm{~B}^{d}$ \\
\hline Streptomyces halstedii & JCM $4584^{\mathrm{T}}\left(=\right.$ ATCC $\left.19770^{\mathrm{T}}\right)$ & $A-1 C$ \\
\hline Streptomyces hygroscopicus & IFO $13472^{\mathrm{T}}\left(=\right.$ ATCC $\left.27438^{\mathrm{T}}\right)$ & $\mathrm{A}-32^{d}$ \\
\hline Streptomyces intermedius & $\mathrm{JCM} 4483^{\mathrm{T}}\left(=\right.$ ATCC $\left.25461^{\mathrm{T}}\right)$ & $\mathrm{A}-1 \mathrm{~A}^{d}$ \\
\hline Streptomyces kanamyceticus & $\mathrm{JCM} 4775^{\mathrm{T}}\left(=\right.$ ATCC $\left.12853^{\mathrm{T}}\right)$ & $\mathrm{B}-42^{d}$ \\
\hline Streptomyces lateritius & JCM $4389^{\mathrm{T}}\left(=\right.$ ATCC $\left.19913^{\mathrm{T}}\right)$ & $\mathbf{H}^{c}$ \\
\hline $\begin{array}{l}\text { Streptomyces lavendulae } \\
\text { subsp. lavendulae }\end{array}$ & IFO $12789^{\mathrm{T}}\left(=\right.$ ATCC $\left.19777^{\mathrm{T}}\right)$ & F-61 \\
\hline Streptomyces longisporoflavus & $\operatorname{JCM} 4396^{\mathbf{T}}\left(=\right.$ ATCC $\left.23932^{\mathbf{T}}\right)$ & A-39 \\
\hline Streptomyces luridus & $\operatorname{JCM} 4591^{\mathrm{T}}\left(=\right.$ ATCC $\left.19782^{\mathrm{T}}\right)$ & F-62 \\
\hline Streptomyces lydicus & JCM $4492^{\mathrm{T}}\left(=\right.$ ATCC $\left.25470^{\mathrm{T}}\right)$ & A-29 \\
\hline Streptomyces massasporeus & $\mathrm{JCM} 4593^{\mathrm{T}}\left(=\right.$ ATCC $\left.19785^{\mathrm{T}}\right)$ & $\mathrm{D}^{c}$ \\
\hline Streptomyces microflavus & JCM $4496^{\mathrm{T}}\left(=\right.$ ATCC $\left.25474^{\mathrm{T}}\right)$ & A-23 \\
\hline Streptomyces misakiensis & JCM $4653^{\mathbf{T}}\left(=\right.$ ATCC $\left.23938^{\mathrm{T}}\right)$ & F-66 \\
\hline Streptomyces nigrescens & $\mathrm{JCM} 4401^{\mathrm{T}}\left(=\operatorname{ATCC} 23941^{\mathrm{T}}\right)$ & $\mathrm{A}-29^{d}$ \\
\hline Streptomyces noboritoensis & $\mathrm{JCM} 4557^{\mathrm{T}}\left(=\operatorname{ATCC} 25477^{\mathrm{T}}\right)$ & A-33 \\
\hline Streptomyces nodosus & JCM $4656^{\mathrm{T}}\left(=\right.$ ATCC $\left.14899^{\mathrm{T}}\right)$ & $\mathrm{A}-35^{e}$ \\
\hline Streptomyces nogalater & JCM $4799^{\mathrm{T}}\left(=\right.$ ATCC $\left.27451^{\mathrm{T}}\right)$ & A-34 \\
\hline Streptomyces novaecaesareae & $\mathrm{JCM} 4800^{\mathrm{T}}\left(=\operatorname{ATCC} 27452^{\mathrm{T}}\right)$ & $\mathrm{J}^{c}$ \\
\hline
\end{tabular}

Continued

firmed that members of the genera Kitasatosporia and Streptoverticillium should be classified in the genus Streptomyces (24), as suggested previously on the basis of $16 \mathrm{~S}$ rRNA analysis data $(32,35)$. The aim of this study was to survey the taxonomic
TABLE $1-$ Continued

\begin{tabular}{|c|c|c|}
\hline Species or subspecies & Strain & $\begin{array}{l}\text { Cluster of } \\
\text { Williams }^{\text {et al. }{ }^{a}}\end{array}$ \\
\hline $\begin{array}{l}\text { Streptomyces ochraceisclero- } \\
\quad \text { ticus }\end{array}$ & $\operatorname{JCM} 4801^{\mathrm{T}}\left(=\operatorname{ATCC} 15814^{\mathrm{T}}\right)$ & A-41 \\
\hline Streptomyces olivaceovinidis & JCM $4499^{\mathrm{T}}\left(=\right.$ ATCC $\left.25478^{\mathrm{T}}\right)$ & A-20 \\
\hline Streptomyces pactum & $\mathrm{JCM} 4809^{\mathrm{T}}\left(=\operatorname{ATCC} 27456^{\mathrm{T}}\right)$ & C-44 \\
\hline Streptomyces panulus & ATCC $12434^{\mathrm{T}}$ & $\mathrm{A}-12^{d}$ \\
\hline $\begin{array}{l}\text { Streptomyces phaeochromo- } \\
\text { genes }\end{array}$ & $\mathrm{JCM} 4659^{\mathrm{T}}\left(=\operatorname{ATCC} 23945^{\mathrm{T}}\right)$ & A-40 \\
\hline Streptomyces poonensis & $\mathrm{JCM} 4815^{\mathrm{T}}\left(=\operatorname{ATCC} 15723^{\mathrm{T}}\right)$ & A-22 \\
\hline Streptomyces prasinopilosus & JCM $4404^{\mathrm{T}}\left(=\right.$ ATCC $\left.19799^{\mathrm{T}}\right)$ & $\mathrm{A}-37^{d}$ \\
\hline Streptomyces prasinosporus & JCM $4816^{\mathrm{T}}\left(=\right.$ ATCC $\left.17918^{\mathrm{T}}\right)$ & A-38 \\
\hline Streptomyces prunicolor & JCM $4508^{\mathrm{T}}\left(=\right.$ ATCC $\left.25487^{\mathrm{T}}\right)$ & A-11 \\
\hline Streptomyces psammoticus & JCM $4434^{\mathrm{T}}\left(=\operatorname{ATCC} 25488^{\mathrm{T}}\right)$ & F-67 \\
\hline Streptomyces purpureus & $\operatorname{JCM} 3172^{\mathrm{T}}\left(=\operatorname{ATCC} 27787^{\mathrm{T}}\right)$ & F-65 \\
\hline Streptomyces ramulosus & $\operatorname{JCM} 4604^{\mathrm{T}}\left(=\right.$ ATCC $\left.19802^{\mathrm{T}}\right)$ & $\mathrm{C}^{c}$ \\
\hline $\begin{array}{l}\text { Streptomyces rimosus subsp. } \\
\text { rimosus }\end{array}$ & $\mathrm{JCM} 4667^{\mathrm{T}}\left(=\operatorname{ATCC} 23955^{\mathrm{T}}\right)$ & B-42 \\
\hline Streptomyces rochei & $\operatorname{JCM} 4074^{\mathrm{T}}\left(=\operatorname{ATCC} 23956^{\mathrm{T}}\right)$ & A-12 \\
\hline Streptomyces sulphureus & JCM $4835^{\mathrm{T}}\left(=\right.$ ATCC $\left.27468^{\mathrm{T}}\right)$ & $\mathrm{C}^{\mathrm{C}}$ \\
\hline Streptomyces tendae & JCM $4610^{\mathrm{T}}\left(=\right.$ ATCC $\left.19812^{\mathrm{T}}\right)$ & $\mathrm{A}-12^{d}$ \\
\hline $\begin{array}{l}\text { Streptomyces thermonitrifi- } \\
\text { cans }\end{array}$ & $\mathrm{JCM} 4841^{\mathrm{T}}\left(=\operatorname{ATCC} 23385^{\mathrm{T}}\right)$ & $\mathrm{A}-36^{d}$ \\
\hline $\begin{array}{l}\text { Streptomyces thermoviolaceus } \\
\text { subsp. thermoviolaceus }\end{array}$ & $\operatorname{JCM} 4843^{\mathrm{T}}\left(=\operatorname{ATCC} 19283^{\mathrm{T}}\right)$ & $C-45^{d}$ \\
\hline Streptomyces thermovulgaris & $\operatorname{JCM} 4520^{\mathrm{T}}\left(=\operatorname{ATCC} 25501^{\mathrm{T}}\right)$ & A-36 \\
\hline Streptomyces tubercidicus & $\mathrm{JCM} 4558^{\mathrm{T}}\left(=\operatorname{ATCC} 25502^{\mathrm{T}}\right)$ & C-47 \\
\hline Streptomyces varsoviensis & JCM $4523^{\mathrm{T}}\left(=\operatorname{ATCC} 25505^{\mathrm{T}}\right)$ & C-46 \\
\hline Streptomyces venezuelae & IFO $13096^{\mathrm{T}}\left(=\right.$ ATCC $\left.25508^{\mathrm{T}}\right)$ & A- $6^{e}$ \\
\hline Streptomyces violaceus & $\operatorname{JCM} 4533^{\mathrm{T}}\left(=\operatorname{ATCC} 25515^{\mathrm{T}}\right)$ & A-6 \\
\hline Streptomyces violaceusniger & $\mathrm{JCM} 4850^{\mathrm{r}}\left(=\operatorname{ATCC} 27477^{\mathrm{T}}\right)$ & A-32 \\
\hline $\begin{array}{l}\text { Streptomyces viridochromoge- } \\
\text { nes }\end{array}$ & $\operatorname{JCM} 4856^{\mathrm{T}}\left(=\operatorname{ATCC} 14920^{\mathrm{T}}\right)$ & A-27 \\
\hline $\begin{array}{l}\text { Streptomyces xanthochromo- } \\
\text { genes }\end{array}$ & JCM $4612^{\mathrm{T}}\left(=\right.$ ATCC $\left.19818^{\mathrm{T}}\right)$ & F-63 \\
\hline Streptomyces xanthocidicus & JCM $4862^{\mathrm{T}}\left(=\operatorname{ATCC} 27480^{\mathrm{T}}\right)$ & $\mathrm{F}-66^{d}$ \\
\hline Streptomyces yerevanensis & $\operatorname{JCM} 3065^{\mathrm{T}}\left(=\operatorname{DSM} 43167^{\mathrm{T}}\right)$ & $\mathrm{D}^{c}$ \\
\hline
\end{tabular}

${ }^{a}$ See reference 34

${ }^{b} \mathrm{~T}=$ type strain.

${ }^{c}$ Single-member cluster.

${ }^{d}$ Subjective synonym in each cluster.

${ }^{e}$ Allied species in each cluster.

structure of streptomycetes by using the AT-L30 analysis method and the numerical phenetic data of Williams et al. (34).

\section{MATERIALS AND METHODS}

Bacterial strains. The Streptomyces species used in this study (Table 1) are species which were listed in Bergey's Manual of Systematic Bacteriology by Williams et al. (33). All of the strains were type strains that were obtained from the Japan Collection of Microorganisms, Saitama, Japan, the Institute of Fermentation, Osaka, Japan, and the American Type Culture Collection, Rockville, Md. Most of the strains were grown in soluble starch-Polypeptone-yeast extract medium at $30^{\circ} \mathrm{C}(26)$; the thermophilic actinomycetes Streptomyces thermonitrificans and Streptomyces thermoviolaceus were grown at 37 and $50^{\circ} \mathrm{C}$, respectively

Preparation of total ribosomal proteins and two-dimensional PAGE. The total ribosomal protein preparation and two-dimensional PAGE procedures were performed by using the method of Kaltschmidt and Wittmann (7), as described in detail previously $(17,24)$. The electrophoretic mobilities (in the first dimension) of the AT-L30 proteins were expressed as relative electrophoretic mobilities compared with the electrophoretic mobility of Saccharomonospora viridis AT-L30 protein, which exhibited the greatest mobility of all of the actinomycete AT-L30 proteins examined (26).

Determination of amino acid sequences. The amino acid sequences of AT-L30 protein samples were determined by using a model $470 \mathrm{~A}$ protein sequencer (Applied Biosystems, Foster City, Calif.) as described previously $(24,25)$. Determination of a maximum of $26 \mathrm{~N}$-terminal amino acids was possible when 100 to 150 pmol of an AT-L30 preparation was used. The $26 \mathrm{~N}$-terminal amino acids 
represent nearly one-half of the whole AT-L30 protein, assuming that the L30 protein of $E$. coli and the AT-L30 proteins of streptomycetes are the same size.

\section{RESULTS}

Two-dimensional PAGE analysis of ribosomal proteins. The ribosomal proteins of 66 species of the genus Streptomyces, as listed by Williams et al. (33) on the basis of numerical phenetic classification data (34), were analyzed by two-dimensional PAGE. The only two species not included were Streptomyces cyaneus and Streptomyces gelaticus, whose ribosomal proteins were difficult to prepare. The electrophoretic mobilities of the proteins identified as AT-L30 proteins in the first dimension of gel electrophoresis were similar for all of the species examined; these proteins exhibited relative electrophoretic mobilities of about 20 . These results are consistent with previous observations $(18,19)$ in that, although there is electrophoretic heterogeneity of AT-L30 proteins among actinomycete genera, each genus has a relative electrophoretic mobility typical of that genus.

N-terminal amino acid sequence analysis of AT-L30 proteins. On the basis of the amino acid sequence homology data (Fig. 1), the strains were classified into five groups (groups I to IV and a nongrouped category). The members of groups I to IV exhibited the same sequence within each group, whereas the strains in the nongrouped category exhibited sequences typical of each species. The same sequences were found in Streptomyces bambergiensis and Streptomyces griseoflavus and in Streptomyces thermovulgaris and Streptomyces cellulosae. For convenience, these pairs of species were classified in the nongrouped category. Altogether, 19 different sequences were found in the genus Streptomyces. Group I was characterized by Arg at position 2; group II strains contained Arg and Val at positions 2 and 5; group III strains contained Gln and Val at positions 2 and 8; and group IV strains contained Gln at position 2 . It is especially noteworthy that all of the members of groups I to IV had Tyr at position 11, a marker position for classification at the genus level $(20,24)$. In contrast, several species classified in the nongrouped category (Streptomyces tubercidicus, Streptomyces rimosus, Streptomyces sulphureus, and Streptomyces albus) had Phe, Ile, or Val at this position. Ser at position 14, together with Tyr at position 11 , has also been considered a signature amino acid characteristic of the genus Streptomyces (24). Interestingly, in Streptomyces sulphureus and Streptomyces albus, Ser at position 14 was also replaced by Thr, indicating that the taxonomic position of these species within the genus was isolated. The amino acids which characterized the species at various loci are indicated in Fig. 1. The N-terminal sequence (Met-Arg-Ile) found in Streptomyces ramulosus and Streptomyces ochraceiscleroticus was especially characteristic.

To express quantitatively the levels of similarity of the amino acid sequences (SAS values), the frequency of appearance of the same amino acid in $26 \mathrm{~N}$-terminal amino acids of the AT-L30 proteins was determined. A difference in the amino acid at position 11 was weighted twofold. On the basis of SAS values determined in this way for a combination of all strains, a dendrogram was drawn (Fig. 2). This dendrogram shows that six clusters were identified. The first cluster contains the members of groups I and II along with several other species; the second cluster contains the members of groups III and IV, as well as several other species; the third cluster contains Streptomyces ramulosus and Streptomyces ochraceiscleroticus; the fourth cluster contains only Streptomyces rimosus; the fifth cluster contains Streptomyces aurantiacus and Streptomyces tuber- cidicus; and the sixth cluster contains Streptomyces albus and Streptomyces sulphureus.

Comparison of the amino acid sequences within one cluster defined by numerical taxonomy. Fifteen species obtained from the culture collection of my laboratory which have been considered subjective synonyms of a cluster representative of Williams et al. (33) were analyzed, and the results are shown in Fig. 3. These results, including the results obtained for three species studied previously (24), are summarized in Table 2, which shows the results of a comparison of the amino acid sequences of the strains tested and their cluster representatives. It is evident that in general, but not always, strains placed in the same cluster by Williams et al. (34) had identical or very similar amino acid sequences, indicating that there was good agreement between the AT-L30 analysis data and the numerical phenetic data. For example, Streptomyces violaceusniger and Streptomyces hygroscopicus, both of which were classified in cluster A-32 by numerical taxonomy methods (34), exhibited complete amino acid sequence similarity. Close phylogenetic relationships between Streptomyces aminophilus and Streptomyces albus (both classified in cluster A-16), between Streptomyces cacaoi and Streptomyces albus (both classified in cluster A-16), and between Streptomyces intermedius and Streptomyces albidoflavus (both classified in A-1A) were especially evident, with characteristic amino acids at specific positions (Table 2). However, discrepancies were also found. For example, Streptomyces kanamyceticus, Streptomyces nodosus, Streptomyces thermoviolaceus, and Streptomyces venezuelae exhibited differences at three loci compared with their cluster representatives; these differences correspond to SAS values as low as $88 \%$. Apparently, these four species are classified in the wrong clusters.

\section{DISCUSSION}

This work was a continuation of previous work (24) involving the Streptomyces species listed by Williams et al. (33). Two main points can be focused on. First, the data from the ribosomal protein AT-L30 analysis provide further evidence that the genus Streptomyces is well circumscribed. This was demonstrated not only by the constant relative electrophoretic mobility value (about 20 ) of the AT-L30 proteins of the Streptomyces species examined but also by the phylogenetic coherence based on $\mathrm{N}$-terminal amino acid sequence homology data. Second, considerable agreement between the results of the ATL30 analyses and the results of the numerical phenetic study of Williams et al. (34) was found. There also were numerous disagreements in details. Despite the significance of streptomycete taxonomy for industrial microbiology, the results of only a few phylogenetic analyses have been published previously, and these analyses dealt with limited numbers of species $(30,32,35)$. Almost all of these studies were performed by using phenetic or chemotaxonomic methods. Therefore, it is difficult at the present time to construct a comprehensive picture in which results of rRNA analyses are included. It is also difficult to discuss my data in relation to previously published DNA homology data (12-14) since the latter data involve few species of the numerous Streptomyces species used in this work. Seki and coworkers (28a) are now attempting to survey the streptomycetes by analyzing numerous strains with $16 \mathrm{~S}$ rRNA sequencing methods. Discrepancies between my AT-L30 data and the numerical phenetic data of Williams et al. (34) and Kämpfer et al. (8) are also evident. Each of the groups classified on the basis of AT-L30 analysis data (groups I to IV) contained species belonging to widely separated clusters in the studies of Williams et al. (34) (Fig. 1) and Kämpfer et al. (8), 
Group I

S. aburaviensis

S. amakusaensis

S. anulatus

S. atroolivaceus

S. aureofaciens

S. badius

S. cal ifornicus

S. finlayi

S. fradiae

S. graninofaciens

S. griseoruber

S. halstedii

S. lavendulae

S. nicrof lavus

S. noboritoens is

S. psamoticus

S. purpureus

S. violaceusniger

S. xanthochromogenes

S. yerevanensis

Group II

S. bikiniensis

S. exfoliatus

S. lateritius

S. Luridus

S. pactur

S. phaeochromogenes

S. prunicolor

S. varsoviensis

Group III

S. chromofuscus

S. filipinensis

S. flaveolus

S. fragil is

S. glaucescens

S. griseoluteus

S. griseoviridis

S. massasporeus

S. nogalater

S. ol ivaceoviridis

S. poonensis

S. prasinosporus

S. rochei

S. violaceus

S. viridochrowogenes
1

5

10

15

20

25

Ala Arg Leu-Lys-Ile-Thr-GIn-Thr-Lys-Ser Tyr-Ile-Gly-Ser-Lys-Gin-Asn-His- ? -Asp-Thr-Leu-Arg-Ser-Leu-Gly A Ala Arg-Leu-Lys-I le-Thr-GIn-Thr-Lys-Ser-Tyr-IIe-Gly-Ser-Lys-GIn-Asn-His-Arg-Asp-Thr-Leu-Arg-Ser-Leu-Gly B Ala Arg-Leu-Lys-I le-Thr-GIn-Thr-Lys-Ser-Tyr-Ile-Gly-Ser-Lys-GIn-Asn-His-Arg-Asp-Thr-Leu- ? -Ser-Leu-Gly A Ala Arg Leu-Lys-I le-Thr-GIn-Thr-Lys-Ser-Tyr-Ile-Gly-Ser-Lys-GIn-Asn-His-Arg-Asp-Thr-Leu- ? -Ser-Leu-Gly A Ala Arg Leu-Lys-I le-Thr-GIn-Thr-Lys-Ser-Tyr Il le-Gly-Ser-Lys-GIn-Asn- ? -Arg-Asp-Thr-Leu-Arg-Ser-Leu-Gly A AlafArg Leu-Lys-Ile-Thr-GIn-Thr-Lys-Ser Tyr-IIe-Gly-Ser-Lys-GIn-Asn-His-Arg-Asp-Thr-Leu- ? -Ser-Leu-Gly C Ala Arg Leu-Lys-I le-Thr-GIn-Thr-Lys-Ser-Tyr-IIe-Gly-Ser-Lys-GIn-Asn-His-Arg-Asp-Thr-Leu- ? -Ser-Leu-Gly A Ala Arg Leu-Lys-I le-Thr-GIn-Thr-Lys-Ser-Tyr Ile-Gly-Ser-Lys-GIn-Asn-His-Arg-Asp-Thr-Leu- ? -Ser-Leu-Gly I Ala Arg Leu-Lys-I le-Thr-GIn-Thr-Lys-Ser-Tyr Ile-Gly-Ser-Lys-GIn-Asn-His-Arg-Asp-Thr-Leu-Arg-Ser-Leu-Gly $G$ Ala Arg Leu-Lys-Ile-Thr-GIn-Thr-Lys-Ser-Tyr IIle-Gly-Ser-Lys-GIn-Asn-His-Arg-Asp-Thr-Leu- ? -Ser-Leu-Gly A AlafArg Leu-Lys-Ile-Thr-GIn-Thr-Lys-Ser Tyr-Ile-Gly-Ser-Lys-GIn-Asn- ? -Arg-Asp-Thr-Leu- ? -Ser-Leu-Gly A Ala Arg Leu-Lys-I le-Thr-GIn-Thr-Lys-Ser-Tyr Il le-Gly-Ser-Lys-GIn-Asn-His-Arg-Asp-Thr-Leu- ? -Ser-Leu-Gly A Al a Arg Leu-Lys-I le-Thr-GIn-Thr-Lys-Ser-Tyr-Ile-Gly-Ser-Lys-GIn-Asn-His-Arg-Asp-Thr-Leu-Arg-Ser-Leu-Gly F Ala Arg Leu-Lys-I le-Thr-GIn-Thr-Lys-Ser Tyr II le-Gly-Ser-Lys-GIn-Asn-His-Arg-Asp-Thr-Leu-Arg-Ser-Leu-Gly A Ala Arg Leu-Lys-I le-Thr-GIn-Thr-Lys-Ser-Tyr Ile-Gly-Ser-Lys-GIn-Asn-His- ? -Asp-Thr-Leu- ? -Ser-Leu-Gly A Ala Arg Leu-Lys-Ile-Thr-GIn-Thr-Lys-Ser Tyr II le-Gly-Ser-Lys-Gin-Asn-His-Arg-Asp-Thr-Leu- ? -Ser-Leu-Gly F Ala Arg Leu-Lys-Il le-Thr-GIn-Thr-Lys-Ser-Tyr-II le-Gly-Ser-Lys-GIn-Asn-His-Arg-Asp-Thr-Leu- ? -Ser-Leu-Gly F Ala Arg Leu-Lys-I le-Thr-GIn-Thr-Lys-Ser-Tyr II le-Gly-Ser-Lys-GIn-Asn-His-Arg-Asp-Thr-Leu- ? -Ser-Leu-Gly A Ala Arg Leu-Lys-Ile-Thr-GIn-Thr-Lys-Ser Tyr Il le-Gly-Ser-Lys-GIn-Asn-His-Arg-Asp-Thr-Leu-Arg-Ser-Leu-Gly F Ala Arg Leu-Lys-Ile-Thr-GIn-Thr-Lys-Ser-Tyr-II le-Gly-Ser-Lys-GIn-Asn-His-Arg-Asp-Thr-Leu-Arg-Ser-Leu-Gly D

$$
1
$$
5

10

15

20

25

Ala Arg Leu-Lys Val-Thr-GIn-Thr-Lys-Ser Tyr HI le-Gly-Ser-Lys-GIn-Asn-His-Arg-Asp-Thr-Leu- ? -Ser-Leu-Gly F Ata Arg Leu-Lys Val Thr-GIn-Thr-Lys-Ser Tyr I le-Gly-Ser-Lys-Gin-Asn-His-Arg-Asp-Thr-Leu-Arg-Ser-Leu-Gly A Ala Arg Leu-Lys Val Thr-GIn-Thr-Lys-Ser Tyr II le-Gly-Ser-Lys-GIn-Asn-His- ? -Asp-Thr-Leu- ? -Ser-Leu-Gly H Ala Arg Leu-Lys Val Thr-GIn-Thr-Lys-SerfTyr II lo-Gly-Ser-Lys-GIn-Asn-His-Arg-Asp-Thr-Leu-Arg-Ser-Lew-Gly F Ala Arg Leu-Lys Val Thr-GIn-Thr-Lys-Ser Tyr II le-Gly-Ser-Lys-GIn-Asn-His-Arg-Asp-Thr-Leu- ? -Ser-Leu-Gly C Ala Arg Leu-Lys Vhal Thr-GIn-Thr-Lys-Ser Tyr Il le-Gly-Ser-Lys-GIn-Asn-His-Arg-Asp-Thr-Leu-Arg-Ser-Leu-Gly A Ala Arg Leu-Lys Val Thr-GIn-Thr-Lys-Ser-Tyr II le-Gly-Ser-Lys-GIn-Asn-His-Arg-Asp-Thr-Leu-Arg-Ser-Leu-Gly A Ala Arg Leu-Lys Val Thr-GIn-Thr-Lys-Ser-Tyr-1I le-Gly-Ser-Lys-GIn-Asn-His-Arg-Asp-Thr-Leu-Arg-Ser-Leu-Gly C 1 5

10

15

20

25 Ala Gln Leu-Lys-Ile-Thr-GIn Val Lys-Ser-Tyr-IIle-Gly-Ser-Lys-GIn-Asn- ? - ? -Asp-Thr-Lou- ? -Ser-Leu-Gly A Ala GIn Leu-Lys-Ile-Thr-GIn Val LLys-Ser-Tyr-Ile-Gly-Ser-Lys-GIn-Asn- ? - ? -Asp-Thr-Leu- ? -Ser-Lou-Gly A Ala Gin-Leu-Lys-Ile-Thr-GIn Val Lys-Ser-Tyr-Ile-Gly-Ser-Lys-GIn-Asn- ? - ? -Asp-Thr-Lou- ? -Ser-Low-Gly A Ala GIn Leu-Lys-I le-Thr-GIn-Val Llys-Ser-Tyr-Ile-Gly-Ser-Lys-GIn-Asn-His-Arg-Asp-Thr-Leu-Arg-Ser-Leu-Gly G Ala GIn LLeu-Lys-Ile-Thr-GIn Val Llys-Ser-Tyr-Il le-Gly-Ser-Lys-GIn-Asn-His-Arg-Asp-Thr-Leu- ? -Ser-Leu-Gly A Ala-Gin Leu-Lys-Ile-Thr-GIn Val Lys-Ser-Tyr-Ile-Gly-Ser-Lys-GIn-Asn-His-Arg-Asp-Thr-Leu-Arg-Ser-Leu-Gly C Ala GInfLeu-Lys-Ile-Thr-GInfVal Lys-Ser-Tyr Il le-Gly-Ser-Lys-GIn-Asn-His-Arg-Asp-Thr-Leu-Arg-Ser-Leu-Gly A Ala GinfLeu-Lys-Ile-Thr-Gin Val Lys-Ser-Tyr-1 le-Gly-Ser-Lys-Gin-Asn-His-Arg-Asp-Thr-Leu- ? -Ser-Lou-Gly D Ala GIn LLeu-Lys-I le-Thr-GinfVal Lys-Ser-Tyr-I le-Gly-Ser-Lys-GIn-Asn-His-Arg-Asp-Thr-Leu-Arg-Ser-Leu-Gly A Ala Gin Leu-Lys-Ile-Thr-GIn-Val Lys-Ser-Tyr-Ile-Gly-Ser-Lys-GIn-Asn-His-Arg-Asp-Thr-Leu- ? -Ser-Leu-Gly A Ala Gin Leu-Lys-Ile-Thr-GinfVal Lys-Ser Tyr II le-Gly-Ser-Lys-GIn-Asn-His-Arg-Asp-Thr-Leu-Arg-Ser-Leu-Gly A Ala GIn LLeu-Lys-I le-Thr-GIn Val Lys-Ser Tyr Il le-Gly-Ser-Lys-GIn-Asn-His-Arg-Asp-Thr- ? - ? - ? -Leu-Gly A AlafGIn-Leu-Lys-Ile-Thr-GinfVal LLs-Ser Tyr Ille-Gly-Ser-Lys-GIn-Asn-His-Arg-Asp-Thr-Leu- ? -Ser-Leu-Gly A Ala a GIn LLeu-Lys-Ile-Thr-GinfVal LLys-Ser-Tyr-Ile-Gly-Ser-Lys-GIn-Asn-His-Arg-Asp-Thr-Leu-Arg-Ser-Leu-Gly A AlafGIn Leu-Lys-I le-Thr-GIn Val Lys-Ser Tyr-Ile-Gly-Ser-Lys-GIn-Asn-His- ? -Asp-Thr-Leu- ? -Ser-Leu-Gly A

FIG. 1. Primary structures of N termini of AT-L 30 proteins from Streptomyces species listed in Bergey's Manual of Systematic Bacteriology. Question marks indicate amino acids that were not determined. The amino acids that characterize the species are enclosed in boxes. The letters on the right indicate the cluster groups of Williams et al. (34). 


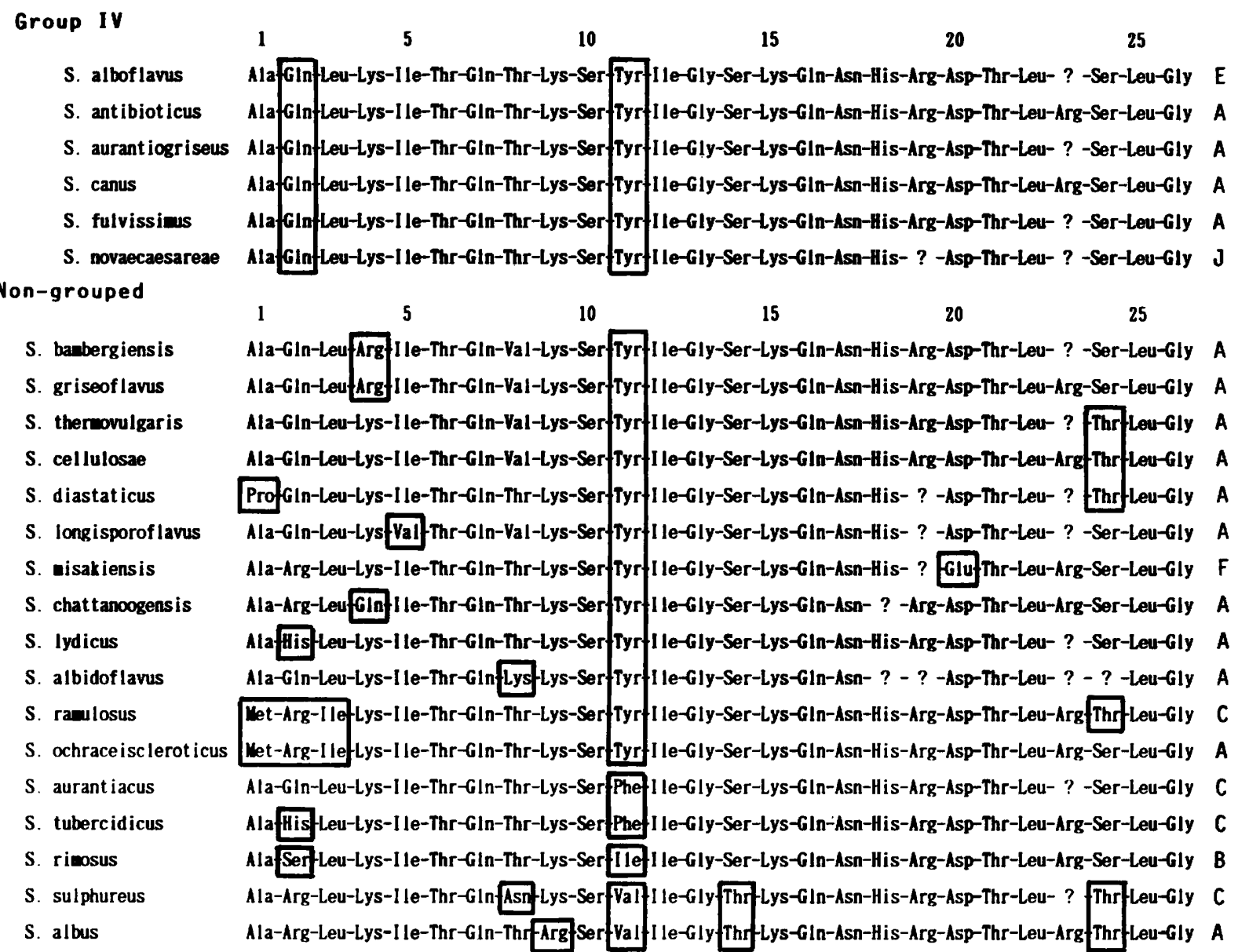

although the following tendencies are evident: group III is composed mainly of organisms that were classified in cluster group A by Williams et al. (34), and groups I and II contain members of cluster group $F$ of Williams et al. (Fig. 1). In addition, no relationship between the four groups and a classical streptomycete character (aerial spore mass color) was found. On the other hand, good agreement was found between the AT-L30 results and the results of 16S rRNA sequencing (28a). For example, group I as defined by AT-L30 data corresponded to specified clusters defined by the $16 \mathrm{~S}$ rRNA data of Seki, while group III corresponded to another cluster of Seki. The agreement between the AT-L30 results and the 16S rRNA results was also evident from the close relationships between Streptomyces lydicus and Streptomyces chattanoogensis, between Streptomyces albidoflavus and Streptomyces diastaticus (both common in freshwater habitats), between Streptomyces aureofaciens and Streptomyces psammoticus, and among Streptomyces californicus, Streptomyces microflavus, and Streptomyces finlayi (Fig. 2) (28a).

The phylogenetic data presented in Fig. 2 are considered taxonomically significant even though a relatively small number of characteristics are involved. In numerical phenetic taxonomy studies $(33,34)$, a close relationship among Streptomyces anulatus (cluster A-1B), Streptomyces halstedii (cluster A-1C), and Streptomyces aburaviensis (cluster A-2) was found. These species were all classified as members of group I in the AT-L30 study. Similarly, Streptomyces californicus (cluster A-9) and Streptomyces fulvissimus (cluster A-10), Streptomyces filipinensis (cluster A-30) and Streptomyces antibioticus (cluster A-31), and Streptomyces lavendulae (cluster F-61) and Streptomyces xanthochromogenes (cluster F-63) were found to be related to one another by numerical taxonomy (34). Streptomyces rimosus, Streptomyces aurantiacus, Streptomyces tubercidicus, Streptomyces sulphureus, and Streptomyces ramulosus, all of which were placed in rather isolated phylogenetic positions within the genus Streptomyces (Fig. 2), have been identified by numerical taxonomy as members of minor cluster group B or $\mathrm{C}$, which is differentiated from major cluster group A. These results are all in good agreement with the results of AT-L30 analyses. Also, Streptomyces albus, which was classified in major cluster group A by numerical taxonomy by Williams et al. (34), was placed in a phylogenetic position that was far removed from the majority of streptomycetes (Fig. 2). Furthermore, in numerical taxonomy studies (34) no close relationship between Streptomyces albus (cluster A-16) and Streptomyces sulphureus (cluster C) was found. However, a close relationship between these two species was detected on the basis of the results of AT-L30 analyses (Fig. 2) and 16S rRNA sequence analyses (28a). Also, the rather distant taxonomic position of Streptomyces albus within the genus has been pointed out by Stackebrandt and coworkers $(30,35)$. Interestingly, unlike the results of Williams et al. (34), the results of another numerical analysis of phenetic traits, the analysis of Kämpfer et al. (8), indicated that Streptomyces albus occupied a rather isolated 


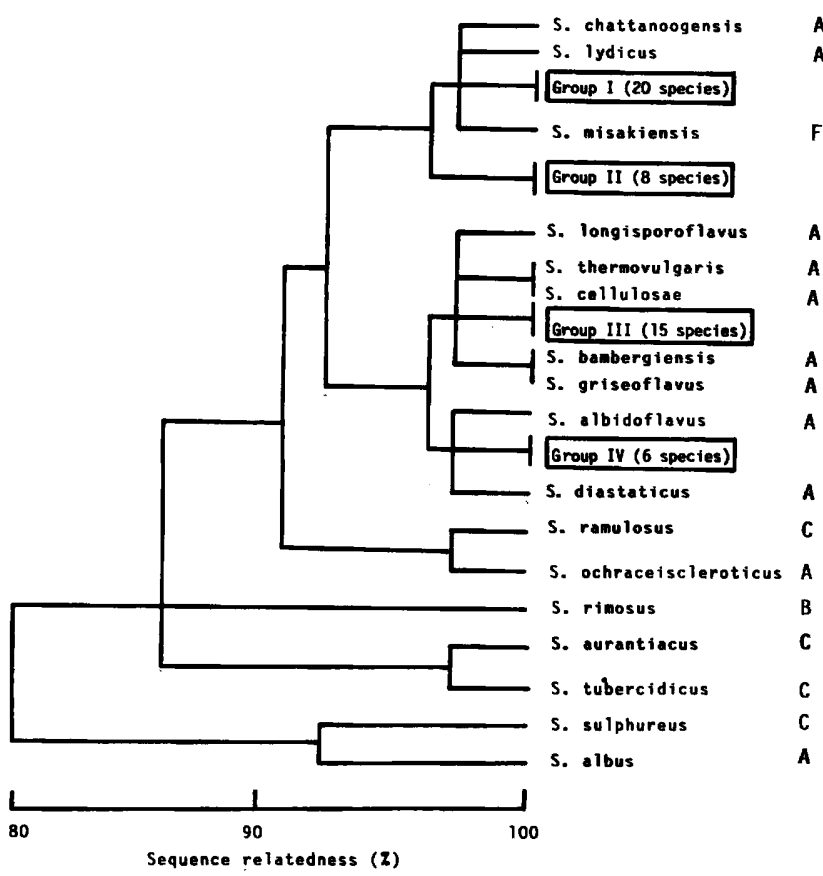

FIG. 2. Clustering based on AT-L30 protein SAS values. The dendrogram was drawn by using the data in Fig. 1. The members of groups I to IV are shown in Fig. 1. The letters on the right indicate the cluster groups of Williams et al. (34).

taxonomic position within the genus Streptomyces, which is consistent with our phylogenetic data. Streptomyces chattanoogensis (cluster A-35) and Streptomyces thermovulgaris (cluster A-36) were found to be closely related by numerical taxonomy (34) but not by AT-L30 analysis (Fig. 2). In summary, the AT-L30 sequence analysis data agreed more with the rRNA analysis data of Seki (28a) and of Stackebrandt and coworkers
$(30,35)$ than with the numerical phenetic analysis data. This is not surprising because AT-L30 analyses and rRNA analyses are both based on molecular analysis of ribosomal components, while numerical taxonomy is based mainly on phenetic data analysis.

Members of the genus Chainia form sclerotia embedded in colonies on agar media or in shake cultures. Members of the genus Microellobosporia form club-shaped sporangia that contain short rows of nonmotile spores and are borne on both the aerial and substrate mycelia. Members of the genus Kitasatoa have also been reported to form club-shaped sporangia on both substrate and aerial hyphae, but produce spores that are motile when they are placed in water. Species of these three genera have been reclassified in the genus Streptomyces (4-6). Streptomyces flaveus and Streptomyces yerevanensis were previously classified in the genus Microellobosporia. Streptomyces ochraceiscleroticus and Streptomyces poonensis were classified in the genus Chainia, and Streptomyces purpureus was classified in the genus Kitasatoa. As shown in this study, all of these species exhibited characteristics typical of the genus Streptomyces, in terms of their relative electrophoretic mobility values and their levels of amino acid sequence homology with other representative streptomycetes. The presence of Tyr at position 11 emphasized the fact that these organisms should be included in the genus Streptomyces.

In a previous study (24), it was shown that all of the Streptomyces species examined had Tyr at position 11. In this study, however, I found a few exceptions to this, including Streptomyces albus, the type species of the genus. Nevertheless, inclusion of these species in the genus Streptomyces is supported by their relative electrophoretic mobility values (about 20), which are typical of the genus, and their relatively high SAS values (80 to $86 \%$ ) (Fig. 2), which are similar to the SAS values of the majority of streptomycetes.

It is clear that ribosomal protein AT-L30 analysis is valuable for defining the genus Streptomyces. My finding that there are at least 19 different $\mathrm{N}$-terminal amino acid sequences of $\mathrm{AT}$ -

15010

10

15

20

25

S. aninophi lus Ala-Arg-Leu-Lys-Ile-Thr-GIn-Asn-Arg-Ser-Val-Ile-Gly-Thr-Lys-GIn-Asn-His-Arg-Asp-Thr-Leu-Arg-Thr- ? -Gly

S. bluensis Ala-GIn-Leu-Lys-I le-Thr-GIn-VaI-Lys-Ser-Tyr-Ile-Gly-Ser-Lys-GIn-Asn-His-Arg-Asp-Thr-Leu-Arg-Ser-Leu-Gly

S. cacaoi Ala-Arg-Leu-Lys-I le-Thr-GIn-Asn-Arg-Ser-Val-Ile-Gly-Thr-Lys-GIn-Asn-His-Arg-Asp-Thr-Leu-Arg-Thr-Leu-Gly

S. cyanoal bus Ala-GIn-Leu-Arg-I le-Thr-GIn-Val-Lys-Ser-Tyr-Ile-Gly-Ser-Lys-GIn-Asn-His-Arg-Asp-Thr-Leu-Arg-Ser-Leu-Gly

S. flaveus Ala-GIn-Leu-Lys-Ile-Thr-GIn-Thr-Lys-Ser-Tyr-Ile-Gly-Ser-Lys

S. griseoincarnatus Ala-GIn-Leu-Lys-I le-Thr-GIn-Val-Lys-Ser-Tyr-Ile-Gly-Ser-Lys-GIn-Asn-His-Arg-Asp-Thr-Leu-Arg-Ser-Leu-Gly

S. intermed ius Pro-GIn-Leu-Lys-I le-Thr-GIn-Lys-Lys-Ser-Tyr-Ile-Gly-Ser-Lys-GIn-Asn- ? -Arg-Asp-Thr-Leu- ? -Ser-Leu-Gly

S. kananycet icus Ala-GIn-Leu-Lys-Ile-Thr-GIn-Val-Lys-Ser-Tyr-Ile-Gly-Ser-Lys-GIn-Asn-His-Arg-Asp-Thr-Leu-Arg-Ser-Leu-Gly

S. nigrescens Ala-His-Leu-Lys-I le-Thr-GIn-Thr-Lys-Ser-Tyr-Ile-Gly-Ser-Lys-GIn-Asn-His-Arg-Asp-Thr-Leu-Arg-Ser-Leu-Gly

S. nodosus Ala-GIn-Leu-Lys-Val-Thr-GIn-Thr-Lys-Ser-Tyr-Ile-Gly-Ser-Lys-GIn-Asn-His-Arg-Asp-Thr-Leu-Arg-Ser-Leu-Gly

S. prasinopi losus Ala-GIn-Leu-Arg-I le-Thr-GIn-VaI-Lys-Ser-Tyr-Ile-Gly-Ser-Lys-GIn-Asn-His-Arg-Asp-Thr-Leu-Arg-Ser-Leu-Gly

S. tendae Ala-GIn-Leu-Lys-I le-Thr-GIn-Val-Lys-Ser-Tyr-Ile-Gly-Ser-Lys-GIn-Asn-His-Arg-Asp

S. thermonitrificans Ala-GIn-Leu-Lys-I le-Thr-GIn-Val-Lys-Ser-Tyr-Ile-Gly-Ser-Lys-GIn-Asn-His-Arg-Asp-Thr-Leu-Arg-Thr-Leu-Gly

S. therwoviolaceus Ala-GIn-Leu-Lys-I le-Thr-GIn-Val-Lys-Ser-Tyr-Ile-Gly-Ser-Lys-GIn-Asn-His-Arg-Asp-Thr-Leu-Arg-Thr-Leu-Gly

S. xanthocidicus Ala-Are-Leu-Lys-I le-Thr-GIn-Thr-Lys-Ser-Tyr-Ile-Gly-Ser-Lys-GIn-Asn-His- ? -Asp-Thr-Leu-ArR-Ser-Leu-Gly

FIG. 3. Primary structures of N termini of AT-L30 proteins from Streptomyces species which were listed as subjective synonyms of cluster representatives by Williams et al. in Bergey's Manual of Systematic Bacteriology. The data for cluster representatives are shown in Fig. 1. 
TABLE 2. Results of a comparison of amino acid sequences of AT-L30 proteins from strains classified in a single cluster by Williams et al. ${ }^{a}$

\begin{tabular}{lll}
\hline \multicolumn{1}{c}{ Species examined } & \multicolumn{1}{c}{ Species in same cluster (cluster) } & \multicolumn{1}{c}{ Results of a comparison of amino acid sequences } \\
\hline Streptomyces intermedius & Streptomyces albidoflavus (A-1A) & Different at one locus, but characterized at position 8 \\
Streptomyces griseus & Streptomyces anulatus (A-1B) & Agreement \\
Streptomyces venezuelae & Streptomyces violaceus (A-6) & Different at three loci, in agreement with group II \\
Streptomyces parvulus & Streptomyces rochei (A-12) & Agreement \\
Streptomyces tendae & Streptomyces rochei (A-12) & Agreement \\
Streptomyces griseoincarnatus & Streptomyces cellulosae (A-13) & Different at one locus, in agreement with group III \\
Streptomyces aminophilus & Streptomyces albus (A-16) & Different at one locus, but characterized at positions 9, 11, and 14 \\
Streptomyces cacaoi & Streptomyces albus (A-16) & Different at one locus, but characterized at positions 9, 11, and 14 \\
Streptomyces flaveus & Streptomyces diastaticus (A-19) & Different at one locus, in agreement with group IV \\
Streptomyces nigrescens & Streptomyces lydicus (A-29) & Agreement \\
Streptomyces hygroscopicus & Streptomyces violaceusniger (A-32) & Agreement \\
Streptomyces nodosus & Streptomyces chattanoogensis (A-35) & Different at three loci, in agreement with group IV \\
Streptomyces thermonitrificans & Streptomyces thermovulgaris (A-36) & Agreement \\
Streptomyces cyanoalbus & Streptomyces griseoflavus (A-37) & Agreement \\
Streptomyces prasinopilosus & Streptomyces griseoflavus (A-37) & Agreement \\
Streptomyces bluensis & Streptomyces longisporoflavus (A-39) & Different at one locus, in agreement with group III \\
Streptomyces kanamyceticus & Streptomyces rimosus (B-42) & Different at three loci, in agreement with group III \\
Streptomyces thermoviolaceus & Streptomyces aurantiacus (C-45) & Different at three loci, in agreement with group III \\
Streptomyces xanthocidicus & Streptomyces misakiensis (F-66) & Different at one locus, in agreement with group I \\
\hline
\end{tabular}

a See reference 34 .

${ }^{b}$ Sequence data for Streptomyces griseus, Streptomyces hygroscopicus, and Streptomyces parvulus were obtained from reference 24.

Clusters of Williams et al. (34).

L30 proteins within the genus Streptomyces is important. The agreement found between numerical phenetic data and ATL30 amino acid sequence data is encouraging (Table 2), but several discrepancies which I found may be taxonomically significant and should be clarified by other approaches, such as DNA relatedness analysis. In a previous study it was demonstrated that Thermoactinomyces vulgaris and Thermoactinomyces thalpophilus, whose classification at the species level has been confusing, could be clearly distinguished by a difference in their AT-L30 amino acid sequences (20). As stressed previously (22), sequence analyses of L30 proteins may be useful for demonstrating that some Pseudomonas fluorescens strains or Pseudomonas putida strains represent separate species. It has been pointed out that Streptomyces griseoflavus JCM 4142 is a misidentified strain (24). This strain should be assigned to Streptomyces ochraceiscleroticus (or a related species) on the basis of its complete AT-L30 sequence and the characteristic N-terminal sequence Met-Arg-Ile (Fig. 1). Thus, ribosomal protein AT-L30 analysis is valuable not only for taxonomy at the genus level but also for identifying unknown isolates to the species level.

Polyphasic taxonomy is the goal of modern procaryotic taxonomy $(16,31)$, and it is widely believed that rRNA molecules and sequence analysis of rRNA molecules are the best means presently available for constructing phylogenies. The classification of Williams et al. $(33,34)$, which was based on numerical phenetic analysis data, is considered a useful basis for streptomycete taxonomy. However, results of phylogenetic analyses in which 16S rRNA sequencing and AT-L30 amino acid sequencing are used may need to be included in streptomycete classification schemes, as demonstrated in this study.

\section{ACKNOWLEDGMENTS}

This study was support in part by a grant from the Basic Research Core System.

I thank T. Seki of Osaka University for valuable discussions and R. Hayashi-Tadokoro for skillful secretarial work.

\section{REFERENCES}

1. Gladek, A., M. Mordarski, M. Goodfellow, and S. T. Williams. 1985. Ribosomal ribonucleic acid similarities in the classification of Streptomyces. FEMS Microbiol. Lett. 26:175-180.
2. Goodfellow, M., and T. Cross. 1984. Classification, p. 7-164. In M. Goodfellow, M. Mordarski, and S. T. Williams (ed.), The biology of actinomycetes. Academic Press, London.

3. Goodfellow, M., C. Lonsdale, A. L. James, and O. C. MacNamara. 1987. Rapid biochemical tests for the characterization of streptomycetes. FEMS Microbiol. Lett. 43:39-44.

4. Goodfellow, M., S. T. Williams, and G. Alderson. 1986. Transfer of Chainia species to the genus Streptomyces with amended descriptions of the species. Syst. Appl. Microbiol. 8:55-60.

5. Goodfellow, M., S. T. Williams, and G. Alderson. 1986. Transfer of Elytrosporangium brasiliense Falcao de Morais et al, Microellobosporia cinerea Cross et al., Microellobosporia flavea Cross et al., Microellobosporia grisea (Konev et al.) Pridham and Microellobosporia violacea (Tsyganov et al.) Pridham to the genus Streptomyces with amended descriptions of the species. Syst. Appl. Microbiol. 8:48-54.

6. Goodfellow, M., S. T. Williams, and G. Alderson. 1986. Transfer of Kitasatoa purpurea Matsumae and Hata to the genus Streptomyces as Streptomyces purpureus comb. nov. Syst. Appl. Microbiol. 8:65-66.

7. Kaltschmidt, E., and H. G. Wittmann. 1970. Ribosomal proteins. VII. Twodimensional polyacrylamide gel electrophoresis for finger-printing of ribosomal proteins. Anal. Biochem. 36:401-412.

8. Kämpfer, P., R. M. Kroppenstedt, and W. Dott. 1991. A numerical classification of the genera Streptomyces and Streptoverticillium using miniaturized physiological tests. J. Gen. Microbiol. 137:1831-1891.

9. Kirby, R., and E. P. Rybicki. 1986. Enzyme-linked immunosorbent assay (ELISA) as a means of taxonomic analysis of Streptomyces and related organisms. J. Gen. Microbiol. 132:1891-1894.

10. Korn-Wendisch, F., and H. J. Kutzner. 1992. The family Streptomycetaceae, p. 921-995. In A. Balows, H. G. Trüper, M. Dworkin, W. Harder, and K.-H. Schleifer (ed.), The prokaryotes, vol. 1. Springer-Verlag, Berlin.

11. Korn-Wendisch, F., and J. Schneider. 1992. Phage typing-a useful tool in actinomycete systematics. Gene 115:243-247.

12. Labeda, D. P. 1993. DNA relatedness among strains of the Streptomyces lavendulae phenotypic cluster group. Int. J. Syst. Bacteriol. 43:822-825.

13. Labeda, D. P., and A. J. Lyons. 1991. Deoxyribonucleic acid relatedness among species of the "Streptomyces cyaneus" cluster. Syst. Appl. Microbiol. 14:158-164.

14. Labeda, D. P., and A. J. Lyons. 1991. The Streptomyces violaceusniger cluster is heterogeneous in DNA relatedness among strains: emendation of the descriptions of $S$. violaceusniger and Streptomyces hygroscopicus. Int. J. Syst. Bacteriol. 41:398-401.

15. Mordarski, M., M. Goodfellow, S. T. Williams, and P. H. A. Sneath. 1986. Evaluation of species groups in the genus Streptomyces, p. 517-525. In G. Szabo, S. Biro, and M. Goodfellow (ed.), Biological, biochemical and biomedical aspects of actinomycetes. Akademiai Kiado, Budapest.

16. Murray, R. G. E., D. J. Brenner, R. R. Colwell, P. De Vos, M. Goodfellow, P. A. D. Grimont, N. Pfenning, E. Stackebrandt, and G. A. Zavarzin. 1990. Report of the Ad Hoc Committee on Approaches to Taxonomy within the Proteobacteria. Int. J. Syst. Bacteriol. 40:213-215.

17. Ochi, K. 1989. Heterogeneity of ribosomal proteins among Streptomyces 
species and its application to identification. J. Gen. Microbiol. 135:26352642 .

18. Ochi, K. 1992. Electrophoretic heterogeneity of ribosomal protein AT-L30 among actinomycete genera. Int. J. Syst. Bacteriol. 42:144-150.

19. Ochi, K. 1992. Polyacrylamide gel electrophoresis analysis of ribosomal protein: a new approach for actinomycete taxonomy. Gene 115:261-265.

20. Ochi, K. 1994. Phylogenetic diversity in the genus Bacillus and comparative ribosomal protein AT-L30 analyses of the genus Thermoactinomyces and relatives. Microbiology 140:2165-2171.

21. Ochi, K. 1995. Amino acid sequence analysis of ribosomal protein AT-L30 from members of the family Pseudonocardiaceae. Int. J. Syst. Bacteriol. 45:110-115

22. Ochi, K. 1995. Comparative ribosomal protein sequence analyses of a phylogenetically defined genus, Pseudomonas, and its relatives. Int. J. Syst. Bacteriol. 45:268-273.

23. Ochi, K., K. Haraguchi, and S. Miyadoh. 1993. A taxonomic review of the genus Microbispora by analysis of ribosomal protein AT-L30. Int. J. Syst. Bacteriol. 43:58-62.

24. Ochi, K., and H. Hiranuma. 1994. A taxonomic review of the genera Kitasatosporia and Streptoverticillium by analysis of ribosomal protein AT-L30. Int. J. Syst. Bacteriol. 44:285-292.

25. Ochi, K., and S. Miyadoh. 1992. Polyacrylamide gel electrophoresis analysis of ribosomal protein AT-L30 from an actinomycete genus, Streptosporangium. Int. J. Syst. Bacteriol. 42:151-155.

26. Ochi, K., S. Miyadoh, and T. Tamura. 1991. Polyacrylamide gel electrophoresis analysis of ribosomal protein AT-L30 as a novel approach to actinomycete taxonomy: application to the genera Actinomadura and Microtetraspora. Int. J. Syst. Bacteriol. 41:234-239.

27. O'Donnell, A. G. 1986. Chemical and numerical methods in the characterization of novel isolates, p. 541-549. In G. Szabo, S. Biro, and M. Goodfellow (ed.), Biological, biochemical and biomedical aspects of actinomycetes. Akademiai Kiado, Budapest.

28. Sanglier, J.-J., D. Whitehead, G. S. Saddler, E. V. Ferguson, and M. Goodfellow. 1992. Pyrolysis mass spectrometry as a method for the classification, identification and selection of actinomycetes. Gene 115:235-242.

28a.Seki, T. Personal communication.

29. Skerman, V. B. D., V. McGowan, and P. H. A. Sneath (ed.) 1980. Approved lists of bacterial names. Int. J. Syst. Bacteriol. 30:225-420.

30. Stackebrandt, E., W. Liesack, and D. Witt. 1992. Ribosomal RNA and rDNA sequence analyses. Gene 115:255-260.

31. Wayne, L. G., D. J. Brenner, R. R. Colwell, P. A. D. Grimont, O. Kandler, M. I. Krichevsky, L. H. Moore, W. E. C. Moore, R. G. E. Murray, E Stackebrandt, M. P. Starr, and H, G. Trüper. 1987. Report of the Ad Hoc Committee on Reconciliation of Approaches to Bacterial Systematics. Int. J. Syst. Bacteriol. 37:463-464.

32. Wellington, E. M. H., E. Stackebrandt, D. Sanders, J. Wolstrup, and N. O. G. Jorgensen. 1992. Taxonomic status of Kitasatosporia and proposed unification with Streptomyces on the basis of phenotypic and 16S rRNA analysis and emendation of Streptomyces Waksman and Henrici 1943, 339 AL. Int. J. Syst. Bacteriol. 42:156-160.

33. Williams, S. T. M. Goodfellow, and G. Alderson. 1989. Genus Streptomyces Waksman and Henrici $1943,339^{\text {AL }}$, p. 2452-2492. In S. T. Williams, M. E. Sharpe, and J. G. Holt (ed.), Bergey's manual of systematic bacteriology, vol. 4. The Williams \& Wilkins Co., Baltimore.

34. Williams, S. T., M. Goodfellow, G. Alderson, E. M. H. Wellington, P. H. A Sneath, and M. J. Sackin. 1983. Numerical classification of Streptomyces and related genera. J. Gen. Microbiol. 129:1743-1813.

35. Witt, D., and E. Stackebrandt. 1990. Unification of the genera Streptoverticillium and Streptomyces, and amendation of Streptomyces Waksman and Henrici 1943, 339 AL. Syst. Appl. Microbiol. 13:361-371. 